\title{
Preparedness Response of Indonesian Tax Offices Concerning the Zakat as a Taxable-Income Deduction
}

\author{
Dodik Siswantoro and Sri Nurhayati \\ Universitas Indonesia
}

\begin{abstract}
This paper aims to analyze the preparedness response of tax offices on the issue of the zakat as a taxable-income deduction. Act No. 17/2000, at the top level, and Government regulation No. 60/2010 supports this policy in detail. However, many people do not claim restitution regarding this policy. This paper uses primary data gathered from phone interviews. Seven tax offices, including service centers, were interviewed in March 2012. The paper provides evidence that each tax office had different responses, provided less information, and acted unsupportive on the issue. In addition, the process of restitution for tax claims is difficult and unfavorable from the zakat payer's perspective. New tax regulations must be supported by clear information socialization and efficient tax restitution process from tax the office. Otherwise, it would not be effective as the benefits may be smaller than the effort.
\end{abstract}

Keywords: Zakat, tax office, response, Indonesia, preparedness

\section{INTRODUCTION}

In Indonesia, the growth of the zakat fund is an issue because it is the country with the most Muslims but lacking in zakat fundraising. A zakat, or tithe, is obligatory to Muslims who meet specific requirements. It is a part of the obligatory worship of the creator and indicates a Muslim's compliance level in conducting worship.

In 2011, the zakat fund collected was only $\mathrm{Rp} 1.2$ trillion, while its true potential reached $\mathrm{Rp} 217$ trillion. ${ }^{1}$ This gap indicated that Muslims in Indonesia were reluctant to pay the zakat even though it is one of the five pillars of Islam. This situation is unfortunate because if a zakat fund were collected optimally, problems in poverty might be eradicated. To enhance zakat payments, incentives were given to

\footnotetext{
${ }^{1}$ http://www.hidayatullah.com/read/18116/21/07/20 11/potensi-zakat-indonesia-tahun-2011-mencapairp.-217-triliun.html
}

zakat payers in the form of a deduction in the taxable income. This regulation has been issued in the Act No. 38/1999 on zakat management and supported by the Act No. 17/2000 (replaced by the Act No. $36 / 2008$ ) on taxable income. Moreover, referring to the Act No. 36/2008, this proposal has just been regulated through Government Regulation No. 60/2010, which will take time to be fully implemented. Nevertheless, few Muslims utilize this regulation as the basis with which to use a zakat as a deduction of their taxable income or claim over their zakat payments (restitutions).

This paper investigates the preparedness response of tax offices on the issue of the zakat as a taxable-income deduction. We start with a supporting theory that explains how the regulation on zakat as tax income deductible was issued and previous studies on tax regulation and tax office support. Then, we examine research methodology, how and when the research was conducted, and topics to be 
analyzed. Next, we analyze interview results as the main part of the research. Finally, we conclude the research in general.

\section{THEORETICAL BACKGROUND}

As one of the five pillars in Islam, a zakat must be paid by Muslims who have met the requirement. The zakat and the income tax are different systems. A zakat is based on wealth, while tax is based on income. In Indonesia, a zakat can be deducted from taxable income, while in other countries, such as Malaysia, it can be deducted from the tax paid. Most likely, the impact of a zakat as a tax deduction is bigger than a zakat as a taxable income deduction.

Based on the Act No. 38/1999 on zakat management, the zakat has been a deduction of taxable income in Indonesia since 1999. Moreover, the Ministry of Religious Affairs Decision No. 581/1999 (replaced by the Ministry of Religious Affairs Decision No. 373/2003) and the Act No. 17/2000 on taxable income issued by the Ministry of Finance (replaced by the Act No. 36/2008) which supported it.
Then, the zakat issue was modified under Government Regulation No. 60/2010 on zakat and religious charity and described in detail by the Regulation of the Minister of Finance No. 254/PMK.03/2010. This issue was also delimited under tax office regulation No. PER-6/PJ/2011 on payment practices and No. PER33/PJ/2011 on registered institutions for zakat receivers (see Figure 1). The government approves only 19 institutions to process the zakat as a deduction of taxable income. Approval of a zakat as a deduction of taxable income takes a considerable amount of time to process. In fact, the implementation of this policy is often difficult due to internal factors such as the comprehension and awareness of the tax office and of the policy itself.

Research on preparedness of the tax office in responding to new regulations is scarce. Most research discusses the effectiveness of the new tax policy, tax avoidance, and differences in tax calculation issues. No research has been conducted as to how tax payers make restitutions for overpaid taxes. 


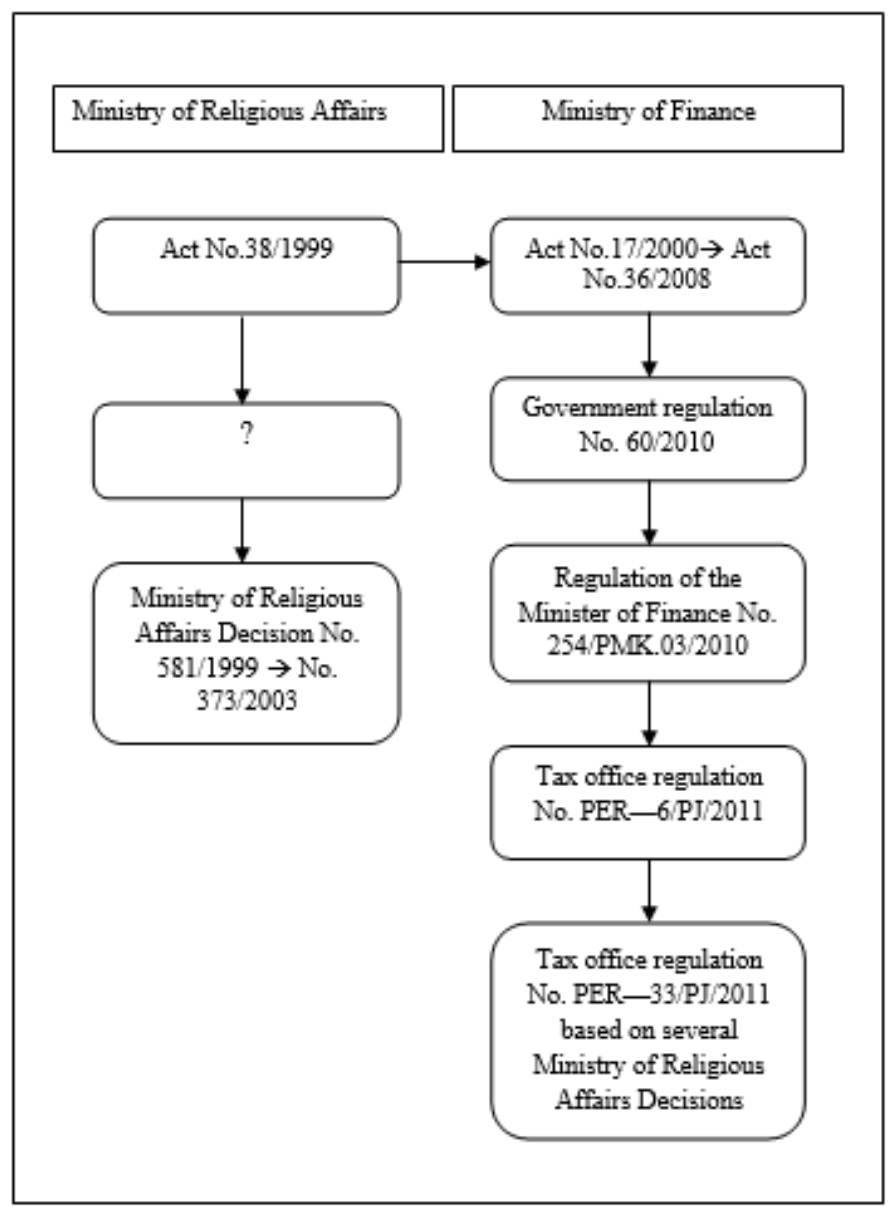

Source: Related regulation

Figure 1. Regulation Hierarchy of Zakat in Indonesia (as a Deduction of Taxable Income)

Several researchers have conducted research on tax office services. Rani and Arora (2011) showed that the implementation of the tax policy is related to tax administration and that a successful implementation of the tax policy must be supported by an efficient tax administration. Ashby et al (2009) argued that taxpayers would be more cooperative if they thought the tax regulations were clearly stated. Similarly, Dijke and Verboon (2010) found that to make taxpayers comply with regulations, tax authorities need to ensure the fairness of tax payment procedures. Furthermore, Cokelc and Oplotnik (2012) argued that good regulations can improve tax services and affect economic growth due to multiple effects. To enhance the performance of tax offices, budget allocations, and incentives to the tax offices should be increased. However, problems may arise in gray areas of the issue.

The tax office's efficiency is also an interesting issue. Katharaki and Tsakas (2010) stated that factors affecting the efficiency of the tax office were scaled to the size of the structure of the regional economy of the tax office. In other words, efficiency of the tax office depends on its size and economic condition.

\section{RESEARCH METHODOLOGY}

The research conducted about the zakat and tax offices employed phone interviews as the primary data-collection method. The period of data collection was from March 2012 to June 2012. Samples were taken 
from seven objects/offices comprising customer service centers, with two different periods of interviews and five different tax office locations in the city and urban areas (region). These seven customer service centers were asked about issues concerning restitution (tax claims) based on related regulations. The main topics included using the zakat as a taxable income deduction and the procedures involved.
Mapping of the interview can be seen in Figure 2. It consists of three parts: (a) first response, (b) the zakat taxable income deduction process, and (c) the payment process of restitution (tax claim). The interview was based on those three parts and then varied depending on tax officers' responses. We map those different responses by using nodes and mapping them into a main category.

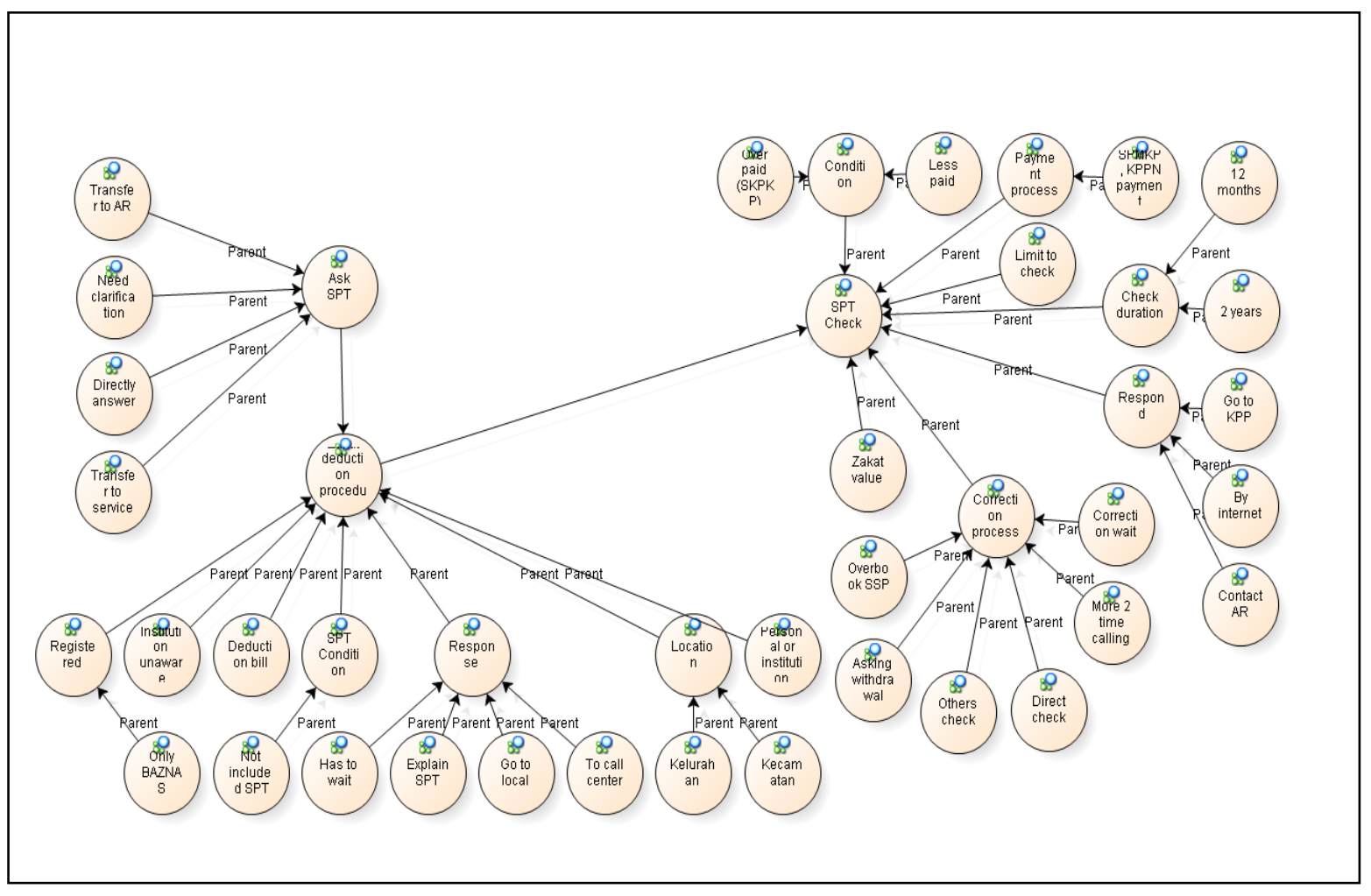

Source: Primary data (2012)

Figure 2. Interview Group Topic 


\section{ANALYSIS}

Analysis of the research started by coding the interview script in nodes (see Table 1). The interview was based on the related issues of topics and preparedness of the tax office concerning the zakat as deductible income. The classification was based on determined characteristics to create crosstab analysis, such as interview length, gender, and city type. Interview length comprised three types: (a) long was above
8 minutes, (b) medium was between 5 and 8 minutes, and (c) quick was below 5 minutes. The gender was determined by whether the tax officer was male or female. City type was categorized by whether the city was located in a large urban area that included a call center and a region with an urban tax office. Word occurrence was also detected, but little of the information could be analyzed (see Appendix 1).

Table 1. Classification of Respondents

\begin{tabular}{lllll}
\hline No & Name & Duration & Sex type & City type \\
\hline 1 & KP1 & Long & Male & City \\
2 & KP & Quick & Female & City \\
3 & PBU & Medium & Male & Region \\
4 & PPJ & Long & Male & City \\
5 & PPS & Long & Male & Region \\
6 & SPG & Medium & Female & Region \\
7 & WPP & Long & Female & City \\
\hline
\end{tabular}

Source: Primary data (2012)

The analysis consisted of three parts: (a) the introductory, or the first response on the zakat as taxable income deduction, (b) zakat process, or the process of the zakat as taxable income deduction, and (c) tax correction, or the process of tax restitution if a taxpayer claimed the overpaid tax payment.

\section{Introductory Response}

NVIVO produced "unassigned" and "not applicable" values, which could be ignored in the analysis. At the first response, most male tax officers suggested that the client contact customer services. Only one female tax officer answered the question directly. Others suggested contacting the account representatives in the related tax office branch. Each taxpayer had an account representative who was responsible for handling his or her tax problems (see Figure 3).

If we classify by city type, only one tax officer answered the issue directly. Whether the tax office was located in a city or region determined its customer service. Two tax offices recommended transferring to account representatives (see Figure 4). 


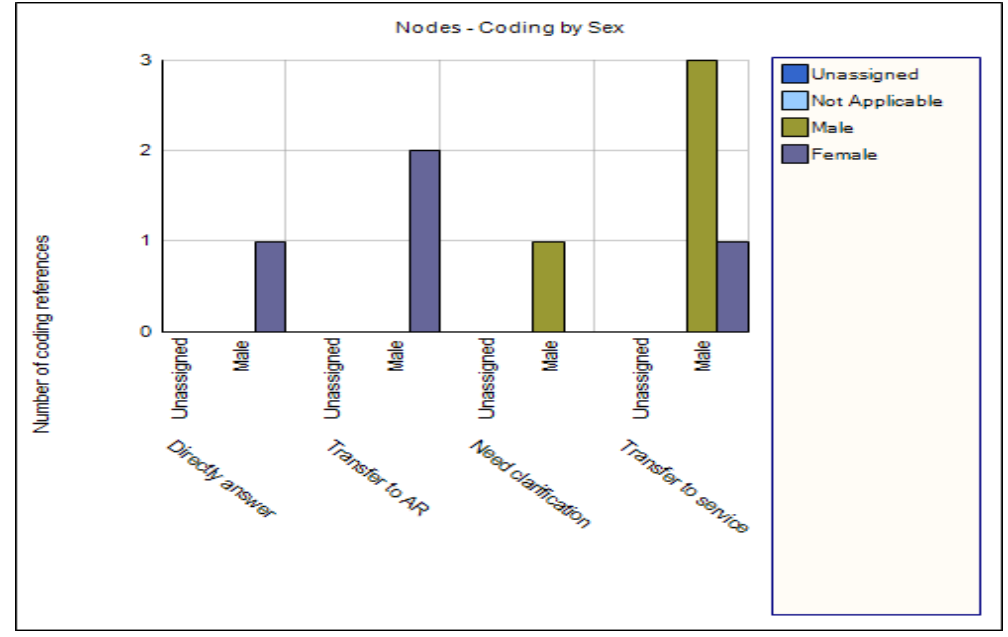

Source: Primary data (2012)

Figure 3. Cross-Tabulation Response and Sex Type

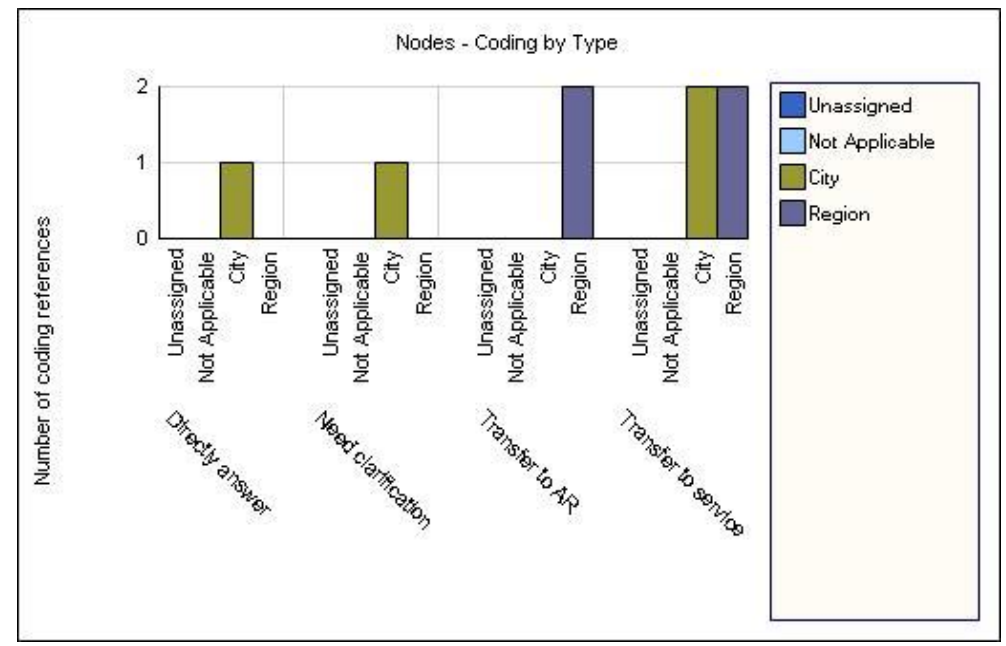

Source: Primary data (2012)

Figure 4. Cross-Tabulation First Response and Type

From both Figures 3 and 4, we can see that there was only one tax officer who could directly respond to the issue of zakat as a taxable income deduction. Others responded differently (for example, they transferred clients to account representatives and customer service). From this early respond, it seems that tax office is not ready to respond this issue.

\section{The Zakat Process}

The second phase of the interview focused on how the zakat could deduct the taxable income. It was a simple mechanism, but it could be difficult to be implemented as there were no clear practices (for example, no other implicit regulations, such as physically checking for restitution). Tax officers asked the taxpayers their addresses, down to the smallest district or village, and above it or the subdistrict. Then, they referred them to the related account representatives. The clients in the subdistrict was asked by the regional tax officer, whereas the clients in the smallest district or village was asked only by the city tax officers (see Figure 5). 


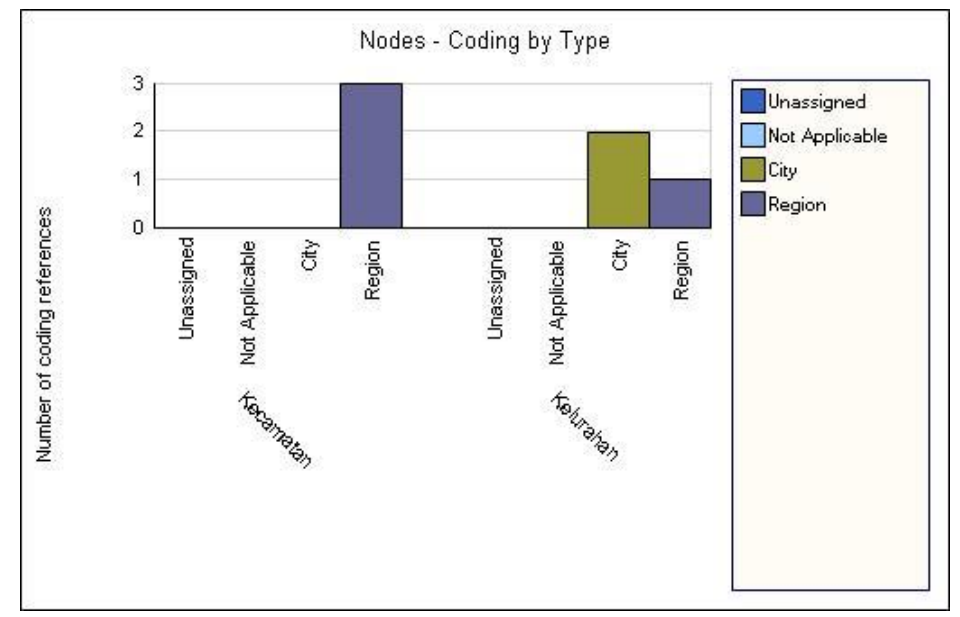

Source: Primary data (2012)

Figure 5. Cross-Tabulation Regional Information and Type

Tax offices gave information about the registered zakat institutions that could deduct taxable income differently. Based on regulations, the zakat could be deducted from taxable income if the taxpayer paid it to a registered tax office (see Figure 6). However, there was one tax office that permitted only the taxpayer to make payments to BAZNAS (National Board of Zakat) in order to get the zakat as a taxable income deduction. Problems occurred when the zakat payer location was isolated or far away from the registered tax office. Taxpayers could not get a deduction of taxable income for these cases. On the other hand, the process to be a registered zakat institution was suspended. Zakat can be deducted if taxpayer pay zakat only to this registered zakat institutions.

Tax offices gave different responses when they had to explain how to get a taxable income deduction in detail. Most tax officers asked the taxpayers to wait to get that information (at city type). Another tax officer referred the client to a local tax office to get the detailed information. Yet another tax officer suggested that the taxpayer contact the call center. Only a small number of tax officers explained how to get the taxable income deduction (see Figure 7).

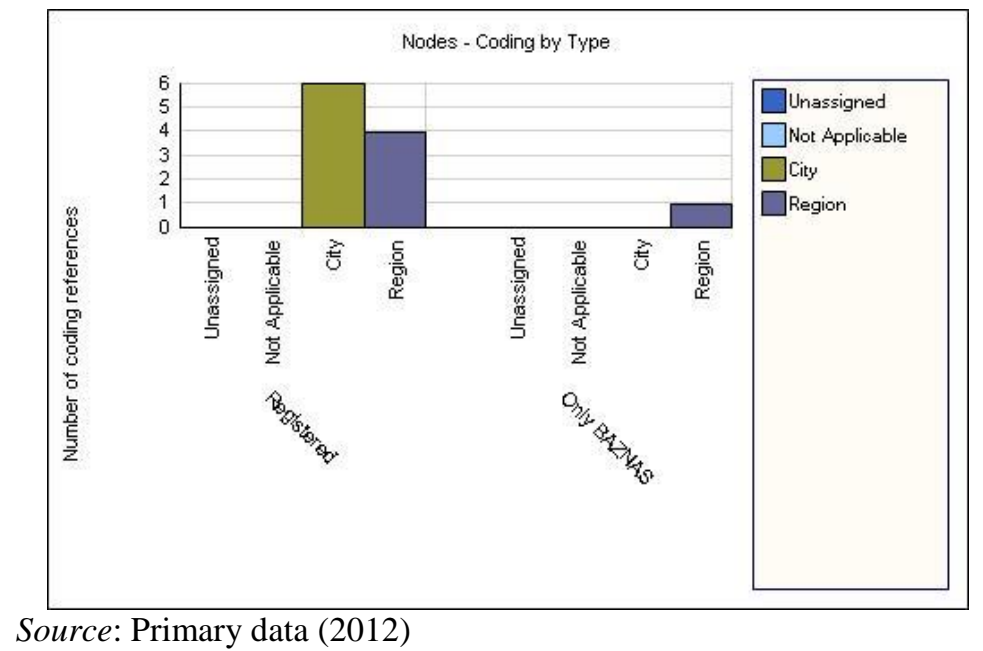

Figure 6. Cross-Tabulation Zakat Institution and Type 


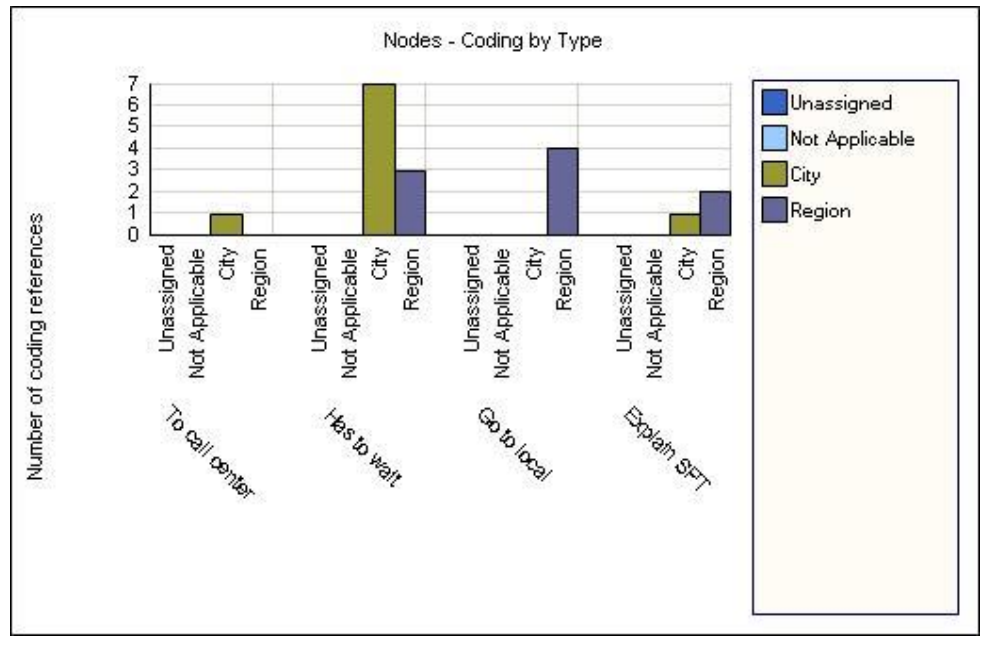

Source: Primary data (2012)

Figure 7. Cross-Tabulation Information Response and Type

Most tax officers said that the deduction bills from registered tax offices were needed to take the taxable income deduction. Interestingly, only one tax office asked whether the zakat payer was from an institution (see figure 8). This is unique because the taxable income deduction applies only to individuals, not institutions.

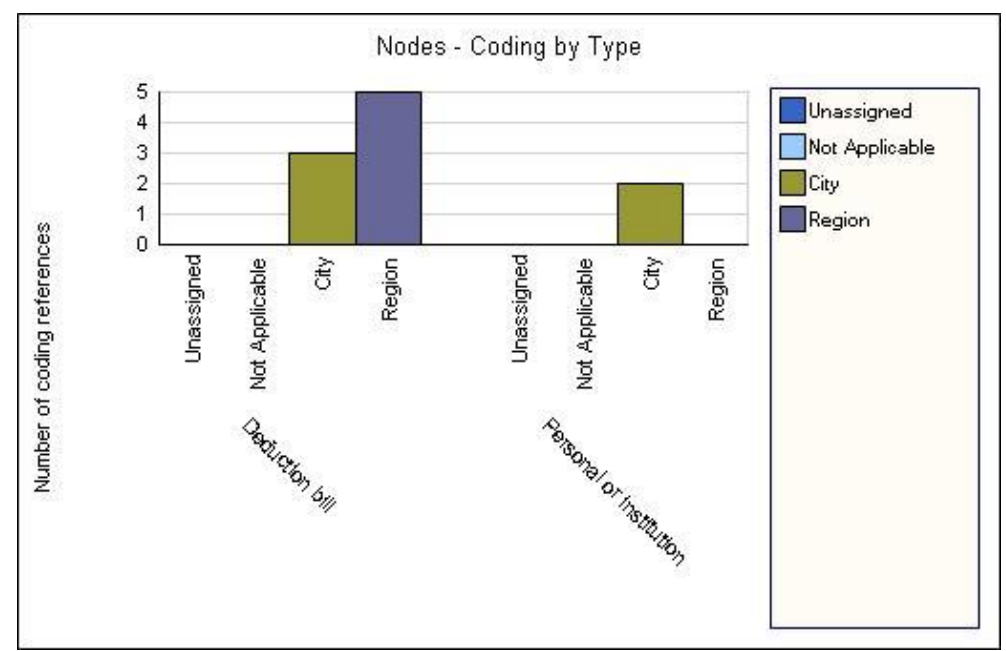

Source: Primary data (2012)

Figure 8. Cross-Tabulation Zakat Information and Type 


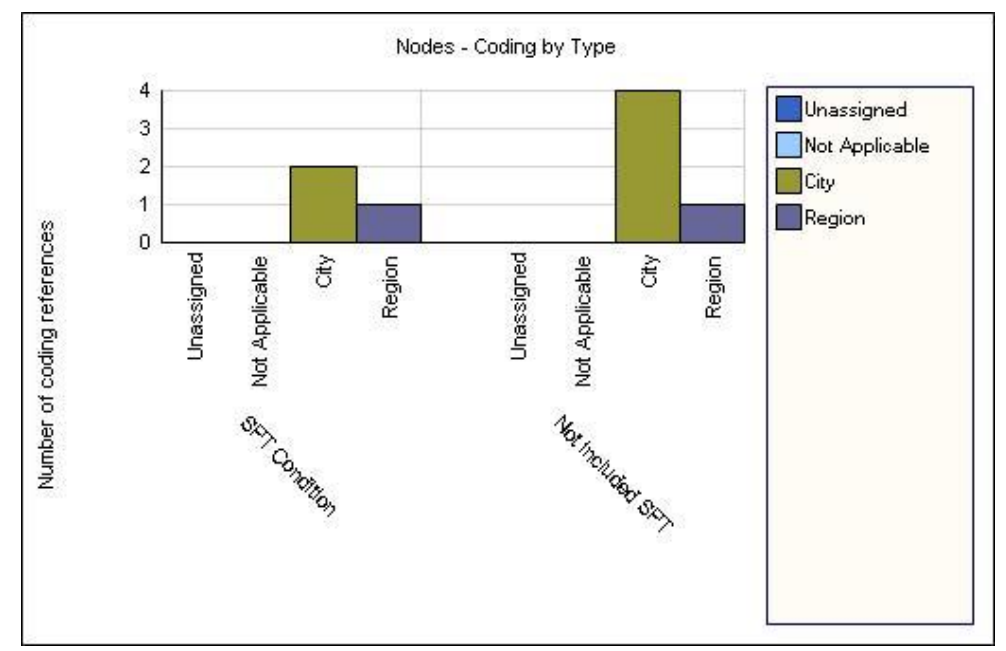

Source: Primary data (2012)

Figure 9. Cross-Tabulation Zakat Condition and Type

Some tax officers asked about the SPT (tax receipt payment report) condition. For taxable income deduction, a blank form must be filled out. Others did not mention anything about the SPT for taxable income deductions (see Figure 9).

\section{Tax Correction}

To get a tax restitution, a tax correction was needed because taxes were paid monthly, whereas the zakat was paid yearly. This caused overpayment of taxes. The zakat for taxable income deduction was not included in the calculation. Responses on tax correction varied. Tax offices suggested that clients reference the Internet or contact account representatives by directly visiting tax offices to get detailed information on this issue (see Figure 10). The process of restitution included tax recalculation, including the zakat amount. Restitution amounts could be retrieved from the gap between with and without involving zakat amount paid in tax calculation. Tax offices gave different periods of time for tax restitution claims, from 1 to 2 years (see Figure 11). Ideally, restitutions could be conducted in one year.

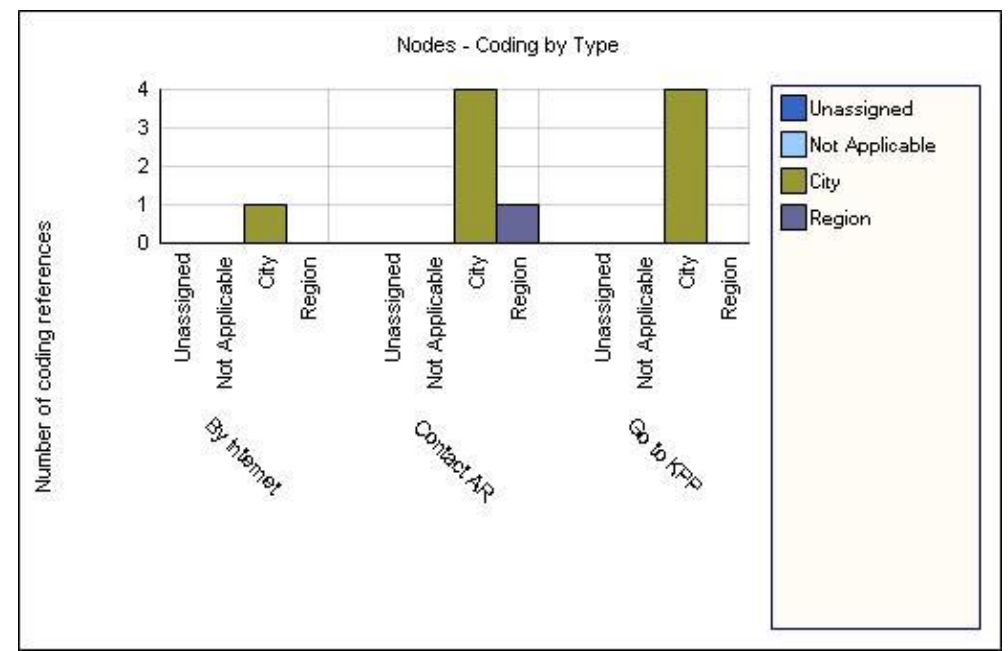

Source: Primary data (2012)

Figure 10. Cross-Tabulation Tax Correction Response and Type 


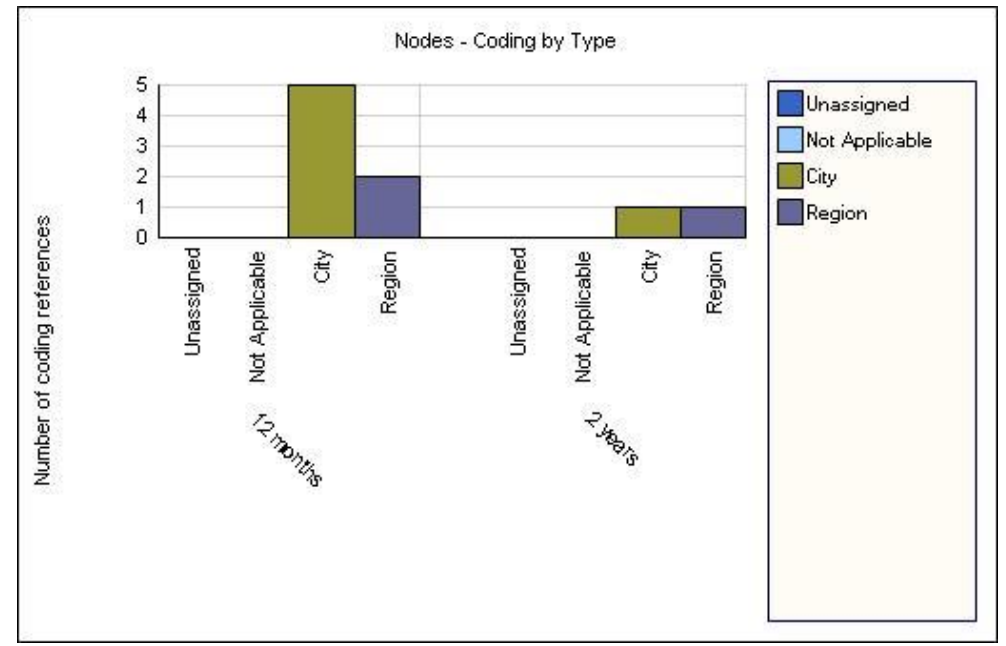

Source: Primary data (2012)

Figure 11. Cross-Tabulation Claim Period and Type

The length of an interview determined the thoroughness with which the tax officer explained the issue. During long interviews, officers could give detailed information regarding the zakat as a taxable income deduction. Quick interviews provided better information than medium-length interviews, which did not discuss the less-paid tax issue (see Figure 12).

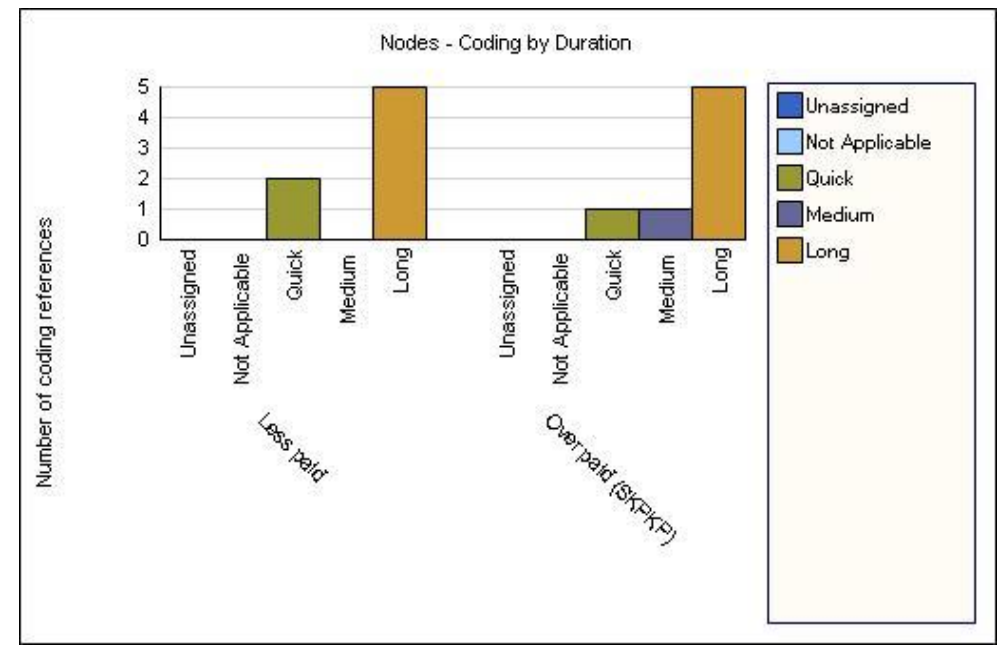

Source: Primary data (2012)

Figure 12. Cross-Tabulation Payment Tax Condition and Interview Length

Furthermore, the tax office's city type determined the quality of information given rather than the region type, even though the number of the tax office "city" is bigger than the "region" (4 compared to
3). The amount of information given doubled between city and region type (see Figure 13). The city type consisted of a call center for tax information and was better prepared to respond to tax issues. 


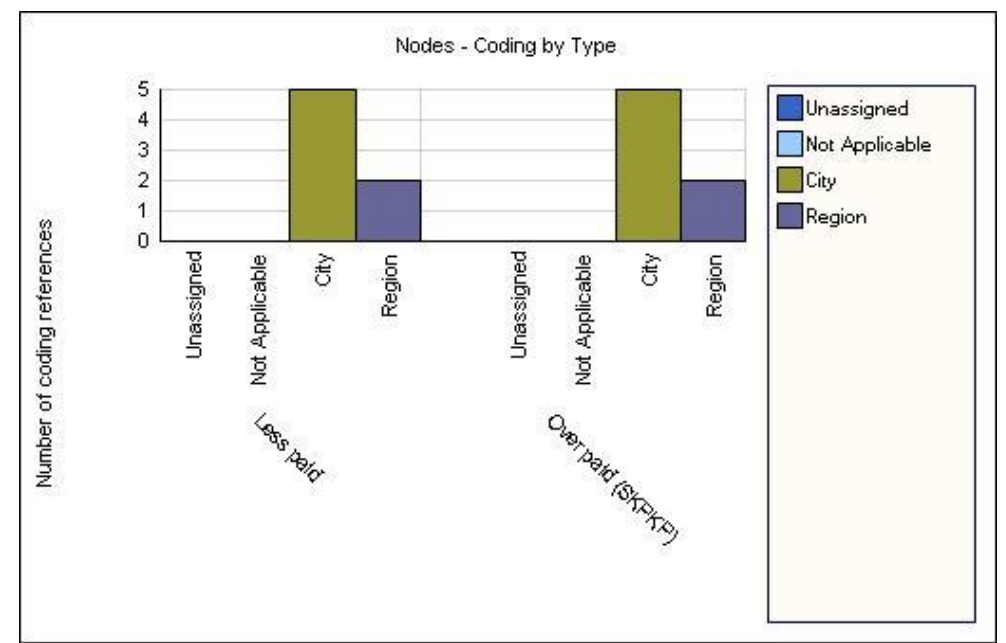

Source: Primary data (2012)

Figure 13. Cross-Tabulation Payment Tax Condition and Type

Tax solutions given by each tax office were different. The city type gave complete solutions, but one proposed to withdraw the restitution because it was complicated and complex. This proposal was not a good solution because restitution is the right of taxpayer. Other solutions offered by the city were (a) correction wait, or a period of waiting; (b) two-time calling, when a taxpayer would be called by a tax office; and (c) overbook SSP, which means a tax is overpaid. While the city and region types both had an equal number for direct checks and other checks, city types were larger (see Figure 14).

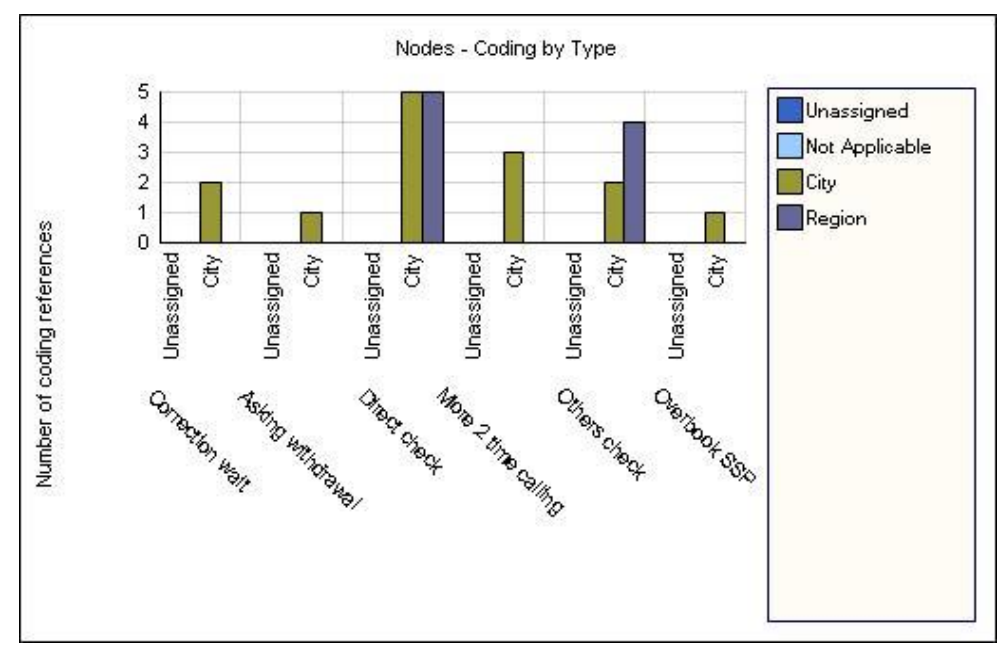

Source: Primary data (2012)

Figure 14. Cross-Tabulation Tax Solution and Type

Regarding the restitution payment mechanism, long interviews gave complete information, but the other lengths did not. The restitution payment was conducted by KPPN (State Treasury Service Office) by issuing an SPMKP (instruction letter to pay). The payment process was explained only during quick and long interviews (see Figure 15). 


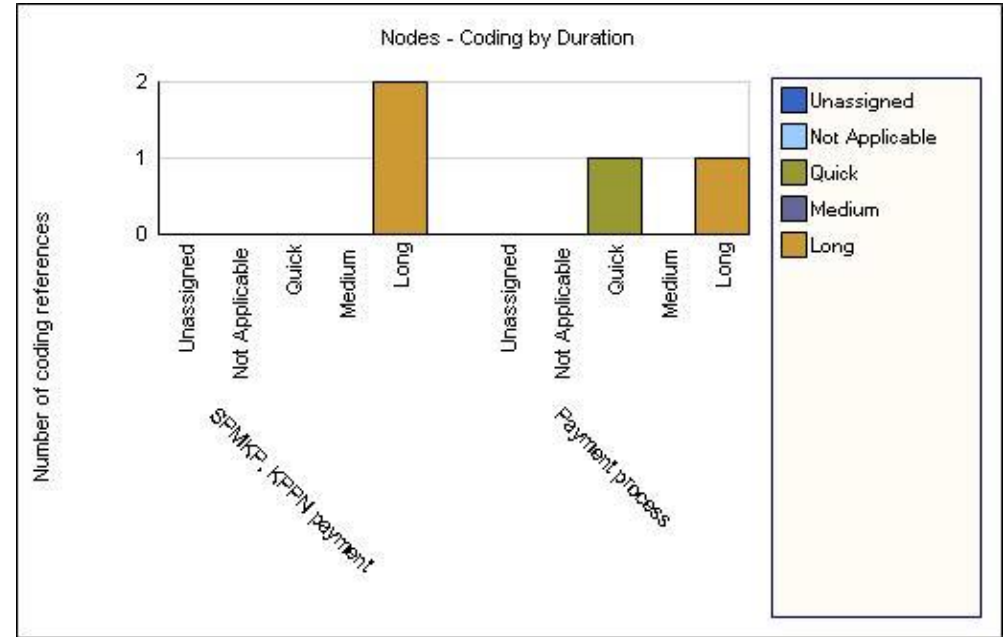

Source: Primary data (2012)

Figure 15. Cross-Tabulation Restitution Payment and Interview Length

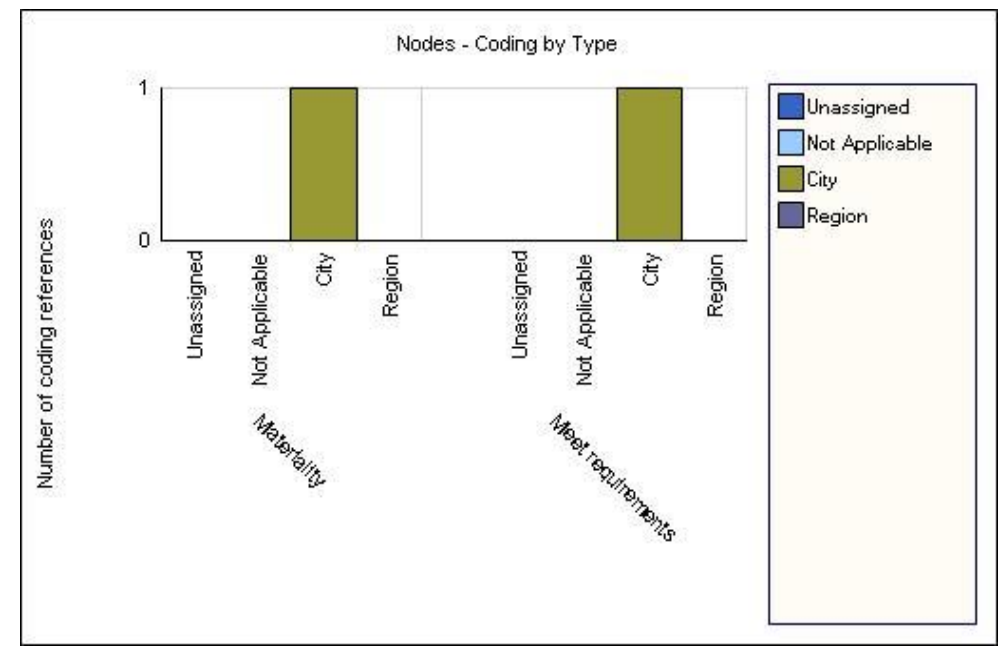

Source: Primary data (2012)

Figure 16. Cross-Tabulation Tax Issue and Type

City tax offices gave other explanations that regional offices did not, such as materiality issues and meeting requirements. Materiality means a taxclaim amount should be bigger than the efforts; otherwise, it is useless. Taxpayers should be aware of requirements that must be fulfilled in order to have restitution (see figure 16). This can be difficult, as the process is quite complicated.

\section{CONCLUSION}

The zakat as a taxable income deduction in Indonesia has been regulated, but some supporting factors may not be conducive. The preparedness of tax offices in responding to the issue of the zakat as a taxable income deduction indicated that they are not prepared. This was seen in the analysis given in the previous section. Tax offices gave varying, improper, and incomplete responses. The more-prepared responses regarding tax issues came from city tax offices or call centers. 
To respond to questions about and to process the zakat as a taxable income deduction, tax officers should know the updated regulations and issues. Circular information can be given daily to upgrade their knowledge and skills.

\section{REFERENCES}

Ashby, J. S., Webley, P., \& Haslam, A. S. 2009. The role of occupational taxpaying cultures in taxpaying behavior and attitudes, Journal of Economic Psychology 30: 216-227.

Cokelc, S., \& Oplotnik, J. Z. 2012. Legal regulation of tax advisory services in relation to their quality. Our Economy 58(3): 16-27.

Dijke, M. V., \& Verboon, P. 2010. Trust in authorities as a boundary condition to procedural fairness effects on tax compliance. Journal of Economic Psychology 31: 80-91.

Directorate General of Tax. 2011. Directorate General of Tax Regulation No. PER-6/PJ/2011 on Implementation of Payment and Invoice of Zakat and Religious Obligatory Charity That Can Deduct Taxable Income.

Directorate General of Tax. 2011. Directorate General of Tax Regulation No. PER-33/PJ/2011 on Registered Institution for Zakat Receiver.

Katharaki, M., \& Tsakas, M. 2010. Assessing the efficiency and managing the performance of Greek tax offices. Journal of Advances in Management Research 7 (1): 58-75.

Minister of State Secretariat. 2000. Act No. 17/2000 on Taxable Income.

Minister of State Secretariat. 2008). Act No. 38/1999 on Zakat Management.

Ministry of Law and Human Rights. 2008. Act No. 36/2008 on Taxable Income.

Ministry of Law and Human Rights. 2010. Governmental Regulation No. 60/2010 on Zakat and Religious Obligatory
Charity That Can Deduct Taxable Income.

Ministry of Law and Human Rights. 2010.

Governmental Regulation No. 254/PMK.03/2010 on Guidance for

Zakat and Religious Obligatory Charity That Can Deduct Taxable Income.

Ministry of Religious Affairs. 1999.

Decision No. 581/1999 on

Implementation Act No. 38/1999 on

Zakat Management.

Ministry of Religious Affairs. 2003. Decision No. 373/2003 on Implementation Act No. 38/1999 on Zakat Management.

Rani, V., \& Arora, R. S. 2011. Perception of tax professionals regarding income tax administration in India. The IUP Journal of Public Finance 9(4): 41-55.

Dodik Siswantoro and Sri Nurhayati

Departement of Accounting

Faculty of Economics and Business

Universitas Indonesia

Kampus UI Depok 16426

Indonesia

dodik.siswantoro@ui.ac.id

This paper was funded by the Directorate of Research and Social Service, Universitas Indonesia. 


\section{APPENDIX}

Appendix 1

Table 2. Most Word Occurrences (in Indonesian)

\begin{tabular}{llll}
\hline Word & Length & Count & Percentage $(\%)$ \\
\hline ya & 2 & 195 & 3.61 \\
itu & 3 & 165 & 3.06 \\
saya & 4 & 151 & 2.80 \\
ibu & 3 & 116 & 2.15 \\
iya & 3 & 107 & 1.98 \\
spt & 3 & 106 & 1.96 \\
kalau & 5 & 102 & 1.89 \\
yang & 4 & 101 & 1.87 \\
begitu & 6 & 100 & 1.85 \\
nanti & 5 & 98 & 1.82 \\
ada & 3 & 84 & 1.56 \\
ke & 2 & 84 & 1.56 \\
mba & 3 & 81 & 1.50 \\
o & 1 & 77 & 1.43 \\
tidak & 5 & 77 & 1.43 \\
bisa & 4 & 75 & 1.39 \\
nya & 3 & 75 & 1.39 \\
ini & 3 & 62 & 1.15 \\
jadi & 4 & 60 & 1.11 \\
bayar & 5 & 58 & 1.07
\end{tabular}

